\title{
Vitamin D and muscle function
}

\section{Heike A. Bischoff-Ferrari}

Department of Rheumatology and Institute for Physical Medicine University Hospital Zurich, Switzerland

Address for correspondence:

Heike A. Bischoff-Ferrari, M.P.H.

Department of Rheumatology and Institute for Physical Medicine University Hospital Zurich

Gloriastrasse 25, 8091 Zurich, Switzerland

Ph. +41 (044) 2552699

Fax +41 (044) 2554388

E-mail: hbischof@hsph.Harvard.edu; Heike.Bischoff@usz.ch

Maintenance of musculoskeletal function and fall prevention are important public health targets in a rapidly aging population (1). Sarkopenia is prevalent in older persons and resulting in falls among $30 \%$ percent of those 65 years or older, and 40 $50 \%$ of those 80 years or older $(2,3)$.

Several beneficial effect of vitamin $D$ have been described, the most established one being improved bone mineral density and fracture prevention (4-6). On the other hand, muscle weakness is also a prominent feature of the clinical syndrome of vitamin $D$ deficiency $(7,8)$ and may plausibly mediate fracture risk through an increased susceptibility to falls (7, 9-13). In fact, vitamin D appears to directly improve muscle strength $(14,15)$ and effects on muscle strength occur within 8-12 weeks (10, 11, 16).

A possible explanation for the beneficial effect of vitamin $D$ on fall risk is that 1,25-dihydroxyvitamin $D$, the active vitamin $D$ metabolite, binds to a highly specific nuclear receptor in muscle tissue $(17,18)$ leading to improved muscle strength and thus to a reduced risk of falling. It is currently believed that, apart from rapid genome-independent calcium fluxes, 1,25-dihydroxyvitamin $\mathrm{D}$ elicits its biological response through the activation of the vitamin D receptor (VDR), which leads to de novo protein synthesis, affecting muscle cell growth $(7,11)$.

In one study, which illustrates this hypothesis, treatment with 1alpha-hydroxyvitamin $D$ increased the relative number and size of type II muscle fibers of elderly women within three months of treatment (11). Furthermore, two RCTs included in the metaanalysis above found a positive effect of vitamin $D$ on body sway (16) and musculoskeletal function (10) in addition to the documented reduction in falls, supporting that fall prevention with vitamin $\mathrm{D}$ is likely to be mediated by improved musculoskeletal function. Pfeifer and colleagues found a $9 \%$ decrease in body sway following a two-month treatment with vitamin D (800 IU per day) plus calcium (1200 mg per day) compared to calcium alone (1200 mg per day) (16). Similarly, Bischoff and colleagues documented a 5-11\% improvement in grip strength, knee extensor and flexor strength, and the timed up\&go test following a three-month treatment with vitamin $D$ (800 IU per day) plus calcium (1200 mg per day) compared to calcium alone (1200 mg per day) (10).

One meta-analysis addressed the effect of vitamin $D$ on the risk of falling in older persons (19). Based on 5 RCTs ( $n=$
1237), vitamin D reduced the risk of falling by $22 \%$ (pooled corrected $\mathrm{OR}=0.78 ; 95 \% \mathrm{Cl}[0.64,0.92]$ ) compared to calcium or placebo $(10,16,20-22)$. Subgroup analyses suggested that the reduction in risk was independent of the type of vitamin $D$, duration of therapy, and gender. However, the results from one trial suggested that $400 \mathrm{IU}$ of vitamin D may not be clinically effective in preventing falls in the elderly (22), while two trials that used $800 \mathrm{IU}$ of vitamin D per day plus calcium reduced the risk of falling $(10,16)$. For the two trials with 259 subjects using 800 IU of cholecalciferol, the corrected pooled OR was 0.65 (95\% $\mathrm{Cl}[0.40,1.00])(19)$. A recent double-blind RCT testing the long-term effect of $700 \mathrm{IU}$ vitamin D plus $500 \mathrm{mg}$ calcium compared to placebo confirmed a benefit on falls among community-dwelling older women $(n=246)$ with a $46 \%$ reduction in the odds of falling (odds ratio [OR], 0.54; $95 \%$ confidence interval [Cl], 0.30-0.97) (23). Fall reduction was most pronounced in less active women (OR, $0.35 ; 95 \% \mathrm{Cl}, 0.15-0.81)$, while the effect in community-dwelling older men was neutral (OR, 0.93; $95 \% \mathrm{Cl}, 0.50-1.72, \mathrm{n}=199)$. The neutral effect in men maybe explained by higher physical activity and higher 25-hydroxyvitamin $\mathrm{D}[25(\mathrm{OH}) \mathrm{D}]$ levels among men in this trial compared to women. Furthermore, the data suggested a possible benefit of vitamin $\mathrm{D}$ on the risk of falling among less active men.

A threshold for optimal 25(OH)D and lower extremity function has been addressed recently (15) examining the association between serum 25(OH)D levels and lower-extremity function in NHANES III including 4100 ambulatory older adults (15). Functional assessment included the 8-foot-walk test and sit-to-stand test $(24,25)$. Both tests depend on lower extremity strength, and mirror functions needed in everyday life. For the 8-foot walk test, compared to the lowest quintile of $25(\mathrm{OH}) \mathrm{D}$, the highest quintile showed an average decrease by $5.6 \%$ (test for trend: $p<0.001)$. For the sit-to-stand test, compared to the lowest quintile of $25(\mathrm{OH}) \mathrm{D}$ the highest quintile showed an average decrease by $3.9 \%$ (test for trend: $p=0.017$ ).

In the regression plots of the NHANES III analysis, performance speed continued to increase throughout the reference range of $25(\mathrm{OH}) \mathrm{D}(22.5$ to $94 \mathrm{nmol} / \mathrm{l})$ with most of the improvement occurring in 25(OH)D levels going from 22.5 to approximately $40 \mathrm{nmol} / \mathrm{l}(15)$. Further improvement was seen in the range of 40-94 nmol. These results were similar for subgroups of active and inactive individuals, men and women, three ethnic groups (Caucasians, African Americans and Mexican Americans), and persons with higher (> $500 \mathrm{mg} /$ day) and lower calcium intakes ( $500 \mathrm{mg} /$ day).

Thus, for all subgroups of ambulatory older individuals the data for lower extremity strength suggested that serum 25(OH)D levels of at least $40 \mathrm{nmol} / \mathrm{l}$ are desirable, but $75-100 \mathrm{nmol} / \mathrm{l}$ are best. This is supported by data published in abstract from the Longitudinal Aging Study Amsterdam including 1351 Dutch men and women aged 65 and older. In that study, a physical performance score (chair stands, a walking test, and a tandem stand) improved most from very low levels of serum 25(OH)D up to $50 \mathrm{nmol} / \mathrm{l}$, and less pronounced but continuously beyond $50 \mathrm{nmol} / \mathrm{l}(26)$.

The optimal target of $75 \mathrm{nmol} / \mathrm{l} 25(\mathrm{OH}) \mathrm{D}$ for lower extremity function is supported by threshold assessment for bone mineral density in younger and older adults (6), fracture efficacy in 
older adults (27), as well as a recent expert consensus for optimal bone health (28). The minimal dose of vitamin $D$ to achieve both fall (19) and fracture prevention (27) has been identified as 700-800 IU vitamin D per day (cholecalciferol). In summary, it has become a public health priority to raise the consciousness of the community towards ensuring sufficient vitamin D status for both fall and fracture prevention, as well as maintenance of muscle strength and lower extremity function. Fall and fracture benefits have been observed with intakes of at least $700-800 \mathrm{IU}$ vitamin D (cholecalciferol) per day and a target level for optimal lower extremity strength and bone health has been suggested to be $75 \mathrm{nmol} / \mathrm{l}(30 \mathrm{ng} / \mathrm{ml})$ 25(OH)D.

\section{References}

1. Leveille SG. Musculoskeletal aging. Curr Opin Rheumatol. 2004; 16(2):114-8.

2. Tinetti ME. Risk factors for falls among elderly persons living in the community. N Engl J Med. 1988;319:1701-1707.

3. Campbell AJ, Reinken J, Allan BC, Martinez GS. Falls in old age: a study of frequency and related clinical factors. Age Ageing. 1981;10(4):264-70.

4. Dawson-Hughes B, Harris SS, Krall EA, Dallal GE. Effect of calcium and vitamin $D$ supplementation on bone density in men and women 65 years of age or older. N Engl J Med. 1997;337(10):670-6.

5. Chapuy MC, Arlot ME, Duboeuf F, et al. Vitamin D3 and calcium to prevent hip fractures in the elderly women. N Engl J Med. 1992; 327(23):1637-42.

6. Bischoff-Ferrari HA, Dietrich T, Orav EJ, Dawson-Hughes B. Positive association between 25 -hydroxy vitamin $D$ levels and bone mineral density: a population-based study of younger and older adults. Am J Med. 2004;116(9):634-9.

7. Boland R. Role of vitamin $D$ in skeletal muscle function. Endocrine Reviews. 1986;7:434-447.

8. Glerup H, Mikkelsen K, Poulsen L, et al. Hypovitaminosis D myopathy without biochemical signs of osteomalacic bone involvement. Calcif Tissue Int. 2000;66(6):419-24.

9. Birge SJ, Haddad JG. 25-hydroxycholecalciferol stimulation of muscle metabolism. J Clin Invest. 1975;56(5):1100-7.

10. Bischoff HA, Stahelin HB, Dick W, et al. Effects of vitamin D and calcium supplementation on falls: a randomized controlled trial. $\mathrm{J}$ Bone Miner Res. 2003;18(2):343-51.

11. Sorensen $\mathrm{OH}$, Lund B, Saltin B, et al. Myopathy in bone loss of ageing: improvement by treatment with 1 alpha-hydroxycholecalciferol and calcium. Clin Sci (Colch). 1979;56(2):157-61.

12. Visser $M$, Deeg DJ, Lips P. Low vitamin $D$ and high parathyroid hormone levels as determinants of loss of muscle strength and muscle mass (sarcopenia): the Longitudinal Aging Study Amsterdam. J Clin Endocrinol Metab. 2003;88(12):5766-72.

13. Sharkey JR, Giuliani C, Haines PS, Branch LG, Busby-Whitehead J, Zohoori N. Summary measure of dietary musculoskeletal nutrient (calcium, vitamin D, magnesium, and phosphorus) intakes is associated with lower-extremity physical performance in homebound elderly men and women. Am J Clin Nutr. 2003;77(4):847-56.
14. Bischoff-Ferrari HA, Borchers M, Gudat F, Durmuller U, Stahelin $H B$, Dick W. Vitamin D receptor expression in human muscle tissue decreases with age. J Bone Miner Res. 2004;19(2):265-9.

15. Bischoff-Ferrari HA, Dietrich T, Orav EJ, et al. Higher 25-hydroxyvitamin $\mathrm{D}$ concentrations are associated with better lower-extremity function in both active and inactive persons aged $60 \mathrm{y}$. Am J Clin Nutr. 2004;80(3):752-8.

16. Pfeifer M, Begerow B, Minne HW, Abrams C, Nachtigall D, Hansen C. Effects of a short-term vitamin D and calcium supplementation on body sway and secondary hyperparathyroidism in elderly women. J Bone Miner Res. 2000;15(6):1113-8.

17. Simpson RU, Franceschi RT, DeLuca HF. Characterization of a specific, high affinity binding macromolecule for 1 alpha, 25-dihydroxyvitamin D3 in cultured chick kidney cells. J Biol Chem. 1980; 255(21):10160-6.

18. Bischoff HA, Borchers M, Gudat F, et al. In situ detection of 1,25dihydroxyvitamin D3 receptor in human skeletal muscle tissue. Histochem J. 2001;33(1):19-24.

19. Bischoff-Ferrari HA, Dawson-Hughes B, Willett CW, et al. Effect of vitamin D on falls: a meta-analysis. JAMA. 2004;291(16):19992006.

20. Gallagher JC, Fowler SE, Detter JR, Sherman SS. Combination treatment with estrogen and calcitriol in the prevention of age-related bone loss. J Clin Endocrinol Metab. 2001;86(8):3618-28.

21. Dukas L, Bischoff HA, Lindpaintner LS, et al. Alfacalcidol reduces the number of fallers in a community-dwelling elderly population with a minimum calcium intake of more than $500 \mathrm{mg}$ daily. $\mathrm{J} \mathrm{Am}$ Geriatr Soc. 2004;52(2):230-236.

22. Graafmans WC, Ooms ME, Hofstee HM, Bezemer PD, Bouter LM, Lips $P$. Falls in the elderly: a prospective study of risk factors and risk profiles. Am J Epidemiol. 1996;143(11):1129-36.

23. Bischoff-Ferrari HA, Orav EJ, Dawson-Hughes B. Effect of cholecalciferol plus calcium on falling in ambulatory older men and women: a 3-year randomized controlled trial. Arch Intern Med. 2006;166(4):424-30.

24. Guralnik JM, Ferrucci L, Simonsick EM, Salive ME, Wallace RB. Lower-extremity function in persons over the age of 70 years as a predictor of subsequent disability. N Engl J Med. 1995;332(9): $556-61$.

25. Seeman TE, Charpentier PA, Berkman LF, et al. Predicting changes in physical performance in a high-functioning elderly cohort: MacArthur studies of successful aging. J Gerontol. 1994; 49(3):M97-108

26. Wicherts IS, Schoor Van NM, Boeke AJP, Lips P. Vitamin D deficiency and neuromuscular performance in the Longitudinal Ading Study Amsterdam (LASA). JBMR 2005; 20 Suppl 1, abstract 1134: S35.

27. Bischoff-Ferrari HA, Willett WC, Wong JB, Giovannucci E, Dietrich $\mathrm{T}$, Dawson-Hughes B. Fracture prevention with vitamin D supplementation: a meta-analysis of randomized controlled trials. JAMA. 2005;293(18):2257-64.

28. Dawson-Hughes B, Heaney RP, Holick MF, Lips P, Meunier PJ, Vieth R. Estimates of optimal vitamin D status. Osteoporos Int. 2005;16(7):713-6. Epub 2005 Mar 18. 